\title{
A Degassing Inlet Structure for Aquaculture Ponds
}

\author{
Joshua M. A. Caasi¹, Eric Krebs², Nathan Huysman², Jill M. Voorhees², Michael E. Barnes²* \\ ${ }^{1}$ School of Engineering, Benedictine College, Atchison, Kansas, USA \\ ${ }^{2}$ McNenny State Fish Hatchery, South Dakota Department of Game, Fish and Parks, Spearfish, South Dakota, USA \\ Email: ^mike.barnes@state.sd.us
}

How to cite this paper: Caasi, J.M.A., Krebs, E., Huysman, N., Voorhees, J.M. and Barnes, M.E. (2020) A Degassing Inlet Structure for Aquaculture Ponds. World Journal of Engineering and Technology, 8, 159-167.

https://doi.org/10.4236/wjet.2020.82013

Received: March 4, 2020

Accepted: March 24, 2020

Published: March 27, 2020

Copyright $\odot 2020$ by author(s) and Scientific Research Publishing Inc. This work is licensed under the Creative Commons Attribution International License (CC BY 4.0).

http://creativecommons.org/licenses/by/4.0/

\begin{abstract}
Structures separating fish hatchery ponds from open spring water sources must restrict fish movement from the pond to the spring, allow for constant water flow, and potentially reduce incoming spring water gas supersaturation. This article describes a novel inlet structure that fulfills those requirements. In addition, it requires minimal maintenance, and allows for the quick and easy removal of debris in the event of partial plugging. This simple aluminum structure consists of a mount for attachment to the inflow pipe and a terminal splash plate with aeration holes. The splash plate is perpendicular to the water flow during normal operations to both prevent fish from jumping into the pipe and aerate the incoming water. However, it can be easily swiveled upward for the efficient removal of debris. Use of the inlet structure consistently decreased gas supersaturation in the spring water as it entered the fish production pond. By decreasing gas levels and maintaining water flows, potentially hazardous fish health issues can be avoided by using this structure. In addition, this relatively inexpensive and simple device will greatly reduce the labor required for removing debris compared to traditional screens.
\end{abstract}

\section{Keywords}

Fish Hatchery, Rearing Pond, Splash Plate, Inlet Structure, Total Gas Pressure

\section{Introduction}

Fish hatchery ponds used during intensive aquaculture require a continuous supply of suitable water [1] [2]. Screens or other structures are typically used to prevent fish movement into water supply lines or open channels used to deliver water to the pond [3] [4]. However, these structures can be plugged with leaves, aquatic vegetation, and other debris, thereby restricting the water flow essential 
for fish production [1] [5].

In addition to the potential problems associated with screens and other structures, using spring water in hatchery ponds may present additional challenges. Spring water frequently contains excess dissolved nitrogen, increasing the risk of gas bubble disease [6] [7] [8] [9]. Acute toxicity of fish occurs at high levels of gas supersaturation, but even chronic exposure to less-than-lethal levels can lead to serious fish health issues [10] [11].

At McNenny State Fish Hatchery, Spearfish, South Dakota, USA, a trout pond was originally separated from its open spring water source by an iron screen, seen in Figure 1. This screen was effective at preventing fish movement from the pond into the spring, but would frequently become plugged with aquatic vegetation, leaves, and woody debris. The maintenance required to clean the screen to maintain water flows was time-intensive and laborious. In addition, the spring water is supersaturated with nitrogen gas, and the screen had no impact on the supersaturated water entering the pond. Thus, a new structure was needed to maintain water flows, reduce labor requirements, and decrease gas supersaturation levels in the spring water before it entered the fish production pond. This manuscript describes a novel mechanism that met those requirements.

\section{Materials and Design}

The water inlet to the pond was modified in two ways. First, the iron screen was removed, and the area formerly occupied by the screen was plugged with concrete to dam the spring. A short section of the upper pond was filled and a 23.56 $\mathrm{cm}$ (ID) polyvinyl chloride pipe was laid in the fill to deliver water from the spring to the new upper pond boundary. A novel inlet structure was attached to the end of the pipe at the pond end (Figure 2). The main components of the inlet structure were constructed using $0.635 \mathrm{~cm}$ thick 6061 -grade aluminum. The

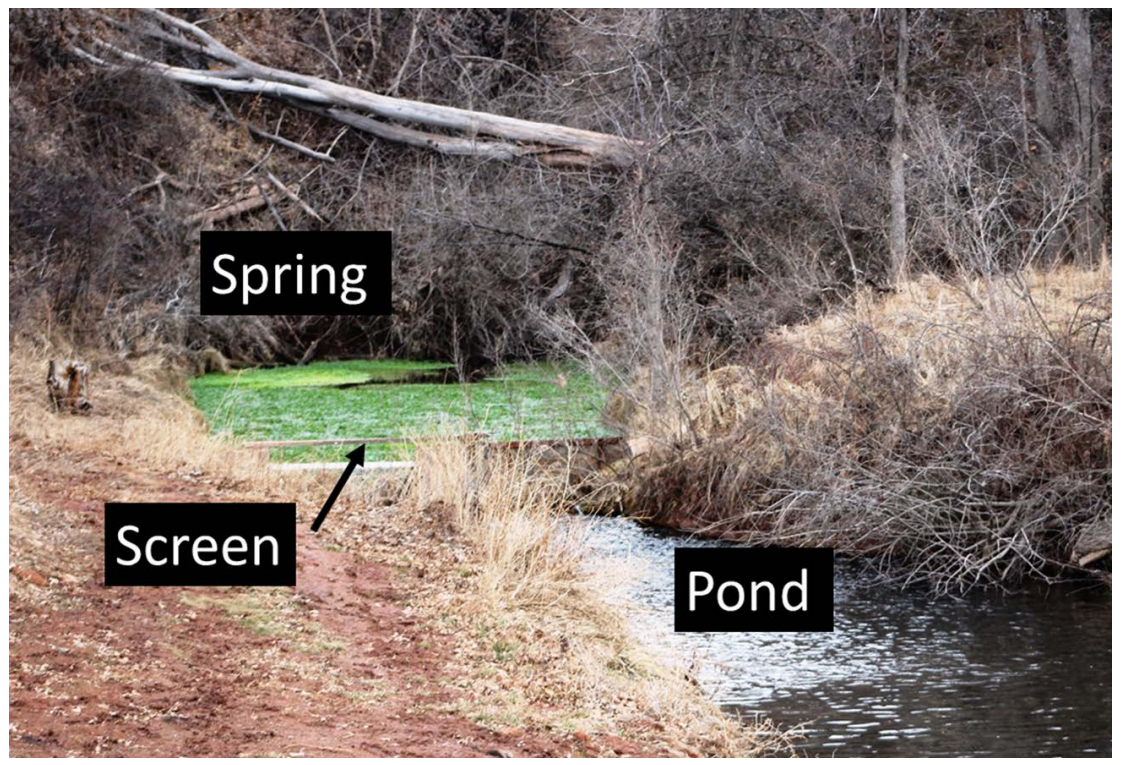

Figure 1. Pre-existing spring and fish rearing pond separated by an iron screen. 


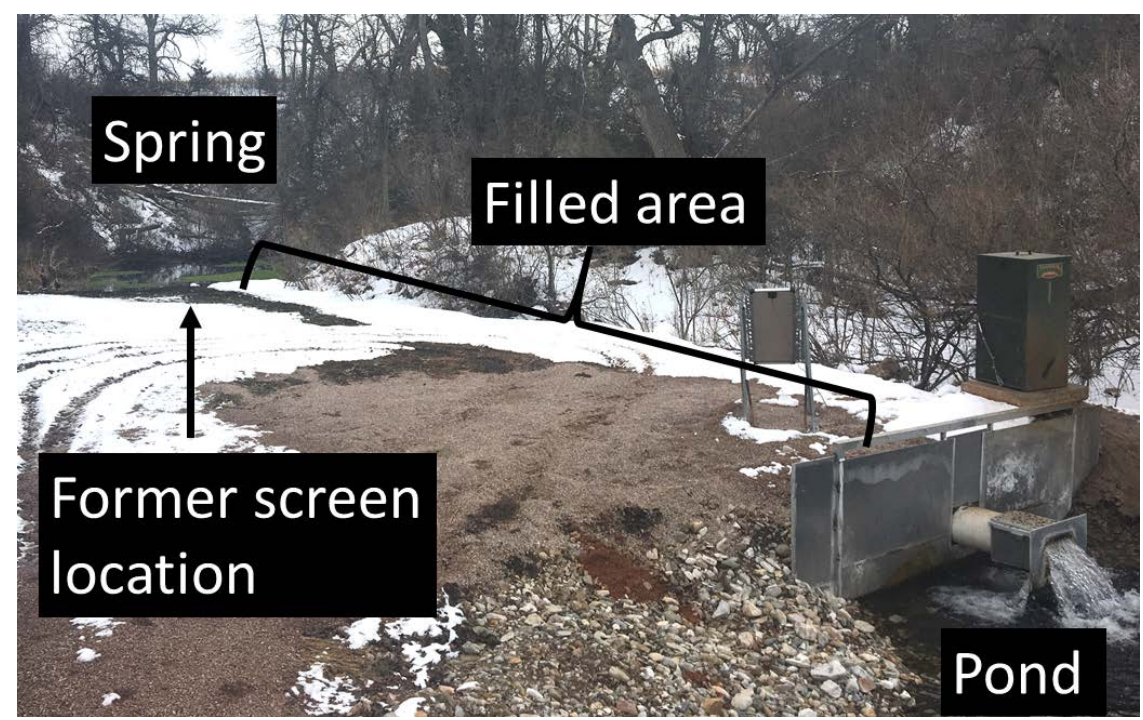

Figure 2. New water delivery system from the open spring to the fish rearing pond. Note the filled area, water pipe, and novel terminal splash plate.

structure consisted of two main components: a splash plate to aerate the water and block fish from entering the pipe, and a mount for attachment to the pipe.

The splash plate, illustrated in Figures 3-5, comprised of a main plate (56.83 $\mathrm{cm} \times 35.56 \mathrm{~cm})$ welded to a smaller plate $(56.83 \mathrm{~cm} \times 10.16 \mathrm{~cm})$ at an angle of $130^{\circ}$ to deter any fish from entering the pipe [4]. Each plate had holes drilled in a symmetrical fashion for water aeration and degassing. Attached to the main plate were two square pipes ( $35.56 \mathrm{~cm}$ long, $2.5 \mathrm{~cm}$ cross section) used as arms to bolt to the mounting apparatus.

The mount, illustrated in Figures 6-8, was comprised of four plates $(25.41 \mathrm{~cm}$ $\times 30.798 \mathrm{~cm}$ ) welded in a box type arrangement. A $7.62 \mathrm{~cm}$ long aluminum angle was welded onto each vertical plate $(5.08 \mathrm{~cm}$ from the top, $7.62 \mathrm{~cm}$ from the left side of the plate). These angles supported the arms of the splash plate so that it maintained a position perpendicular to the water pipe during normal operations.

Two holes were drilled through the vertical plates so that, when bolted, the back faces of the arms were flush with the back face of the mount $3.2 \mathrm{~cm}$ from the hole to the right side of the plate). Two holes were drilled through the top to bolt to the PVC pipe. Each bolted connection (swivel points and pipe) used $0.953 \mathrm{~cm}$ stainless steel $(6.28 \mathrm{~cm}$ long) bolts and $0.953 \mathrm{~cm}$ stainless steel nuts. Models of the structure mounted in cleaning and operating configurations are seen in Figure 9 and Figure 10, respectively.

\section{Evaluation}

This inlet structure was evaluated on three criteria: 1) prevent fish passage, 2) maintain water flows, and 3) decrease dissolved gas levels.

Regarding the potential movement of fish from the pond to the spring, over the course of six months, no fish have been observed in the spring. The angle of the bottom deflector on the splash plate allowed the water to pass but restricted 


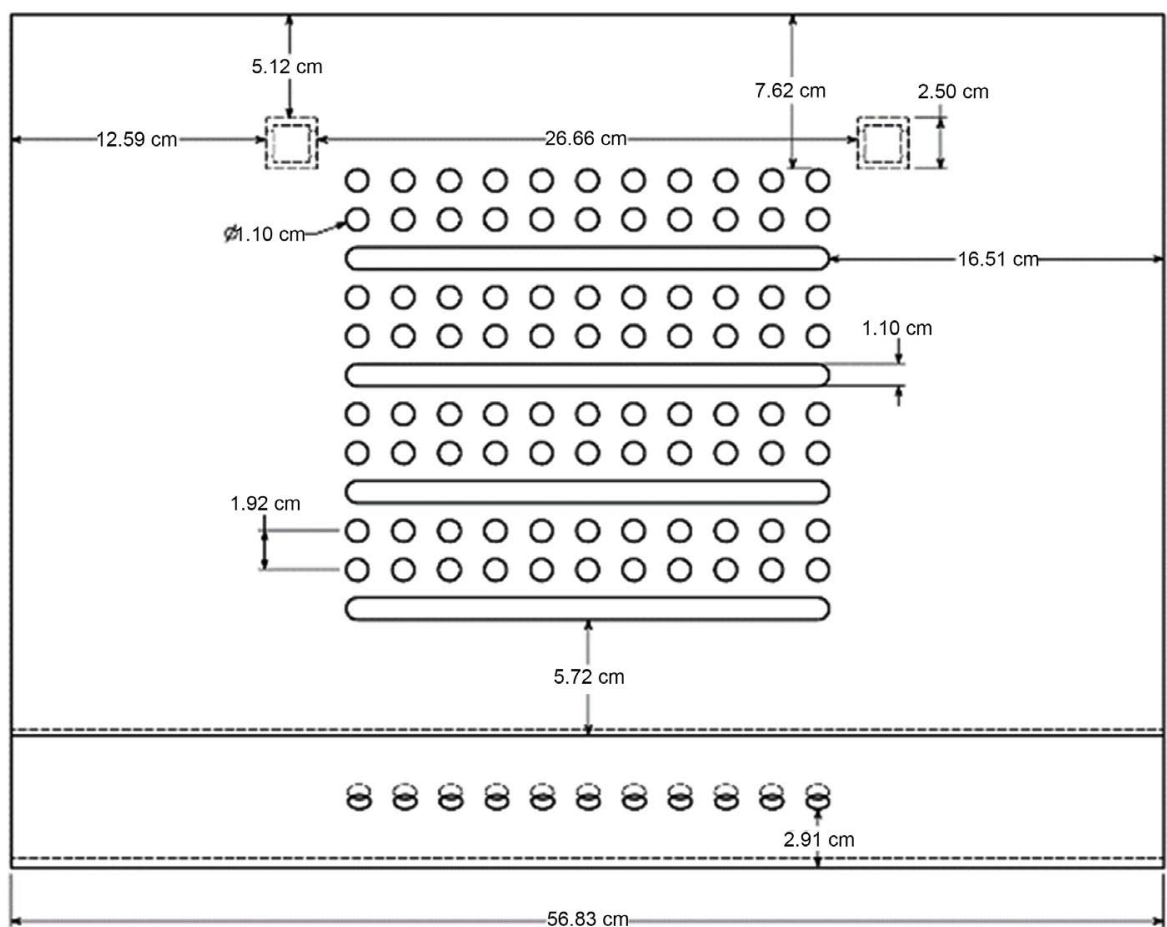

Figure 3. Front profile splash plate schematic.

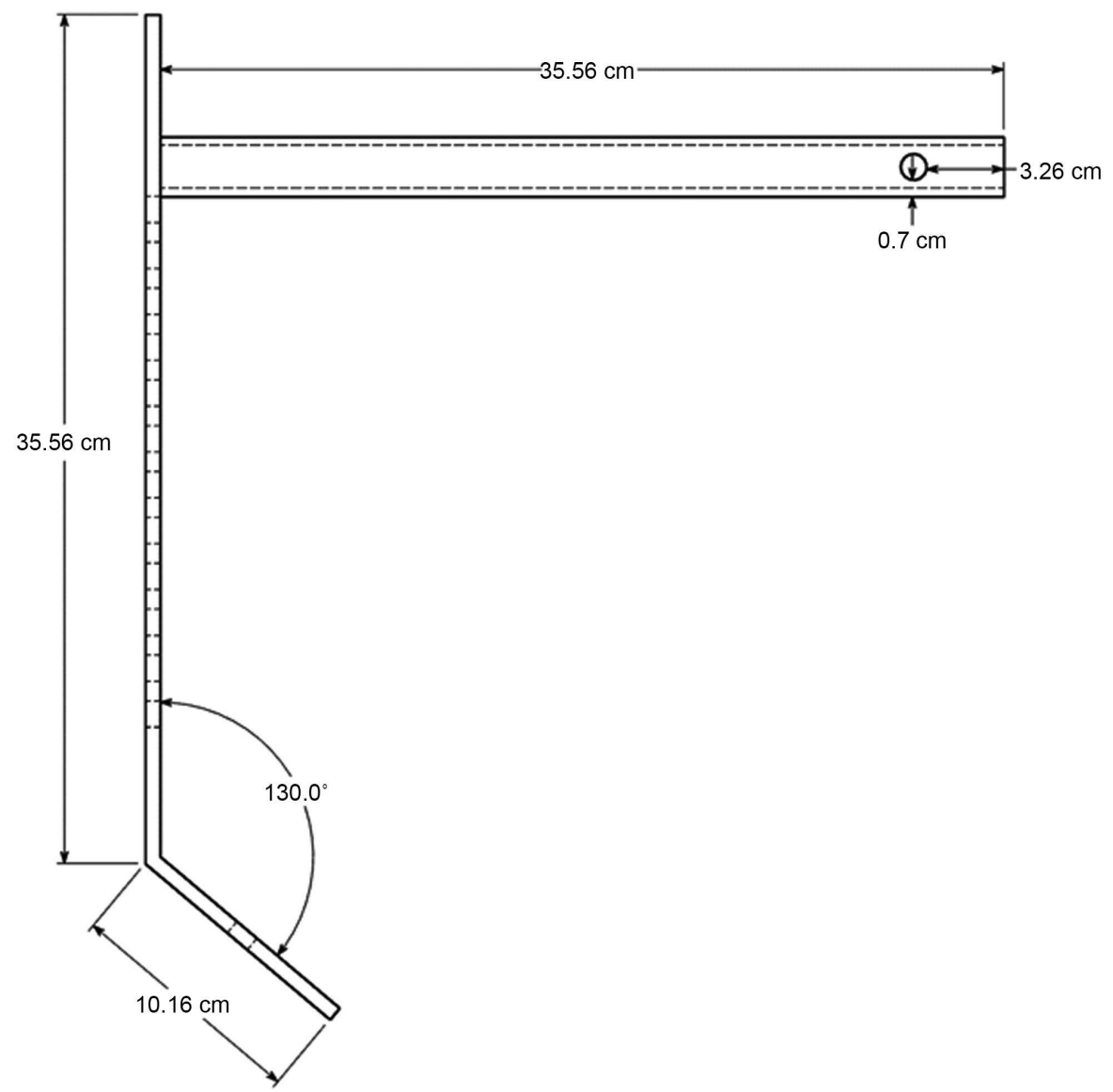

Figure 4. Right profile splash plate schematic. 


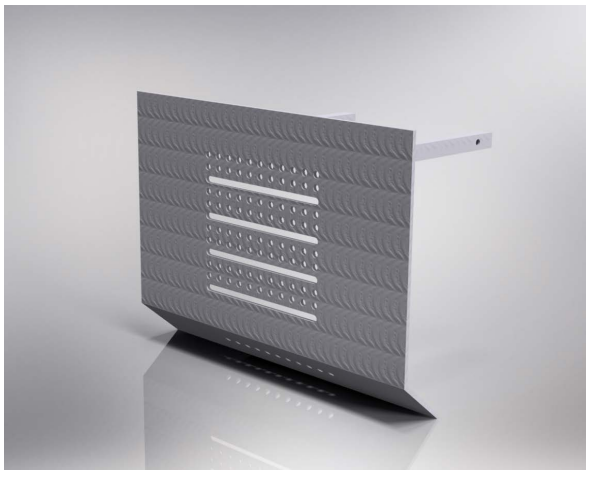

Figure 5. Isometric model of the splash plate. Note the symmetry for left and right sides.

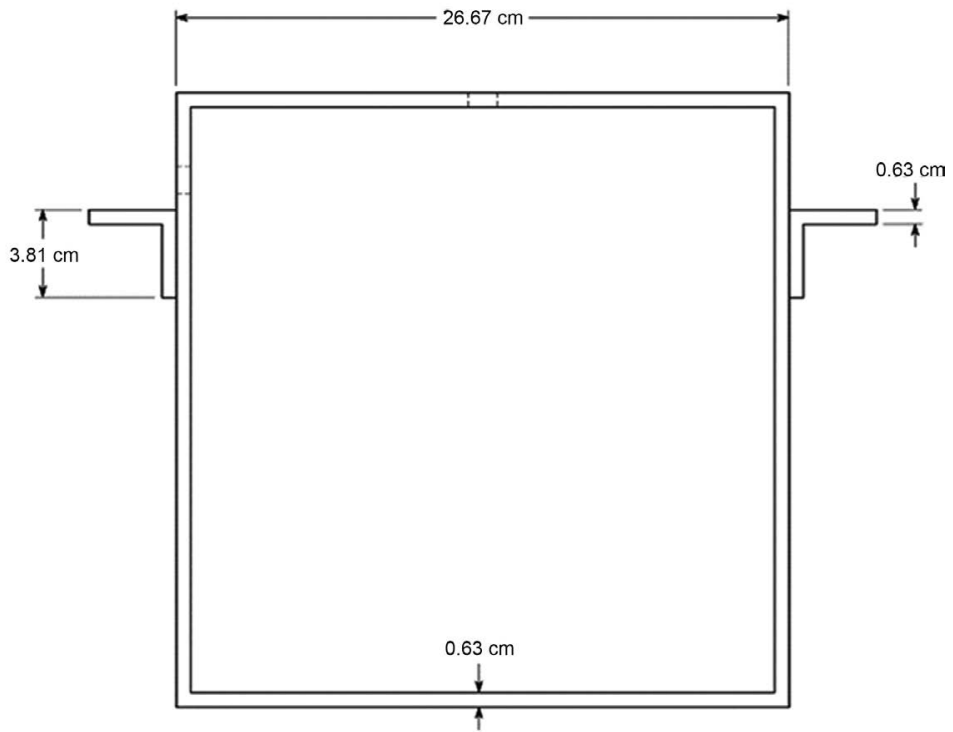

Figure 6. Front profile schematic of the mount.

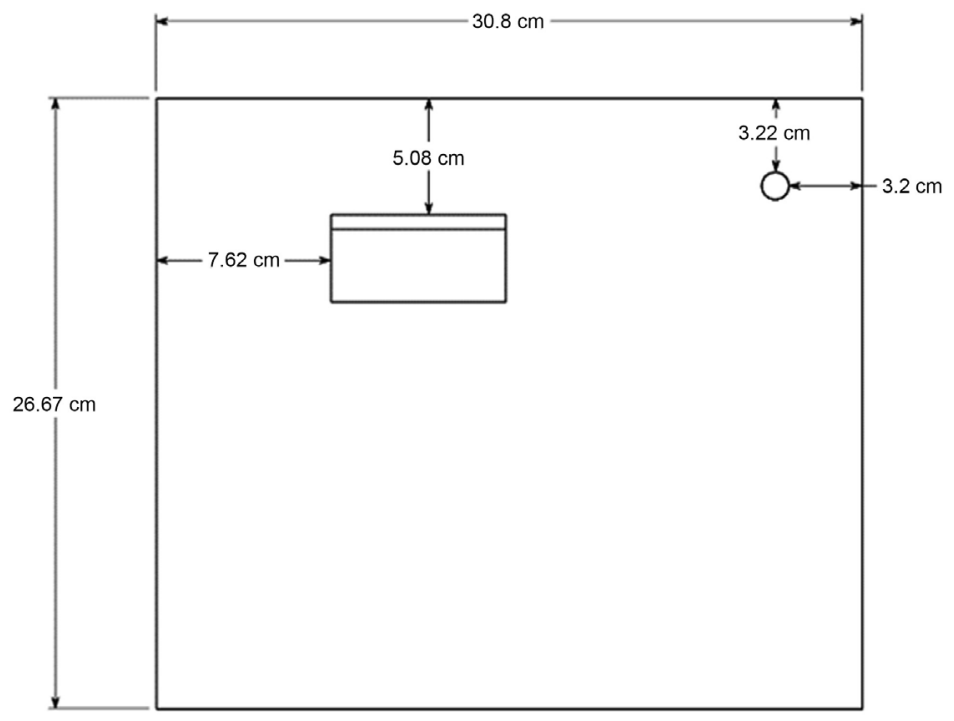

Figure 7. Right profile schematic of the mount. The hole indicates bolt positioning for splash page attachement. 


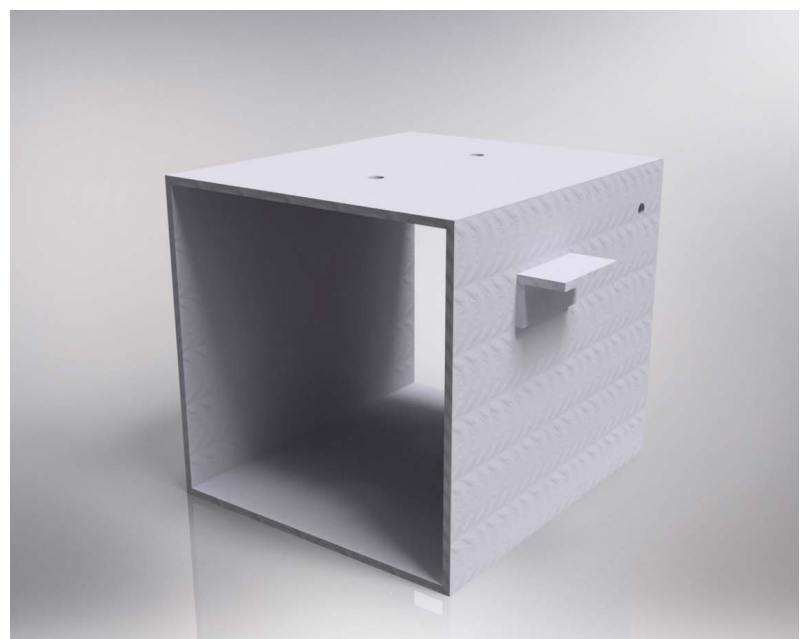

Figure 8. Isometric model of the mount. Note the symmetry for left and right sides and the holes on the top plate for mounting.

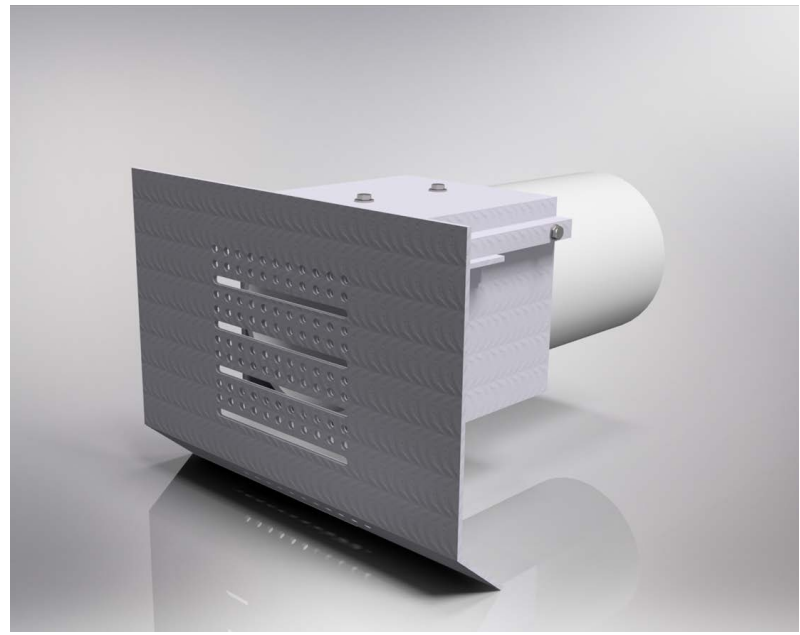

Figure 9. Model in operating position.

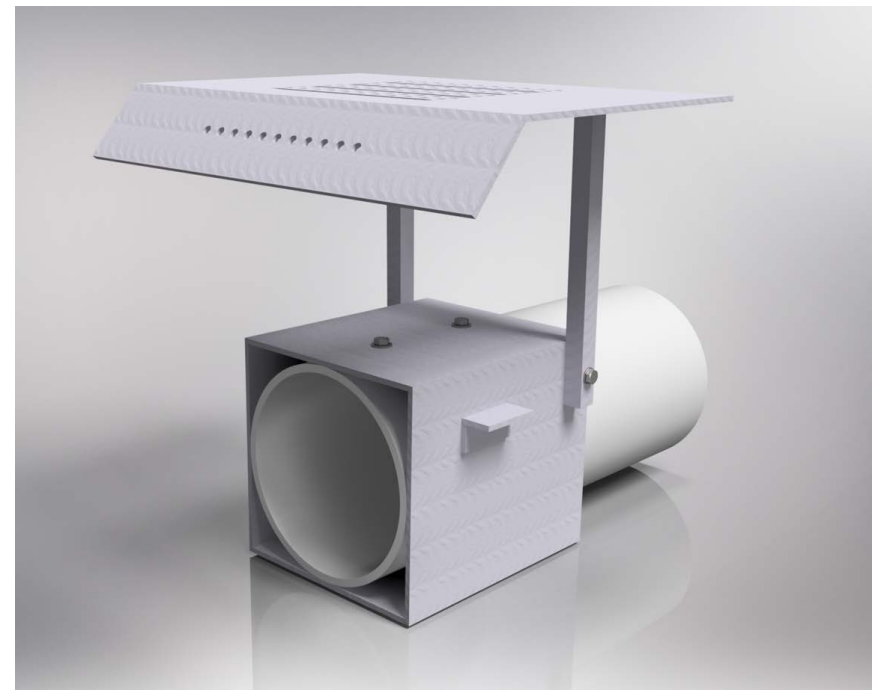

Figure 10. Model in cleaning position. 
the ability of fish to migrate through the structure and into the water pipe, seen in Figure 11 [4].

Water flows, essential for the intensive rearing of trout in the pond, were not impeded at any time during the six-month trial period [2] [12]. Aquatic vegetation and woody debris from the spring would occasionally enter the pipe and become lodged either behind the splash plate or in the splash plate holes and slots. This frequently occurred previously with the iron screen [1] [5]. However, unlike the plugging and restricted water flows associated with the iron screen, in none of these instances with the splash plate were water flows impeded. Also, unlike the prior screen design, removing the materials was quick and efficient: the splash plate was rotated upward, and the materials were dislodged (Figure 12).

Total gas pressures were measured both prior to and after exiting the pond inlet structure using a Handy Polaris TGP meter (OxyGuard, Farum, Denmark) during January and February of 2020. Total gas pressure in the spring water significantly decreased after passing through the inlet structure and splash plate, graphed in Figure 13. Spring water gas pressures were as high as $108 \%$ and

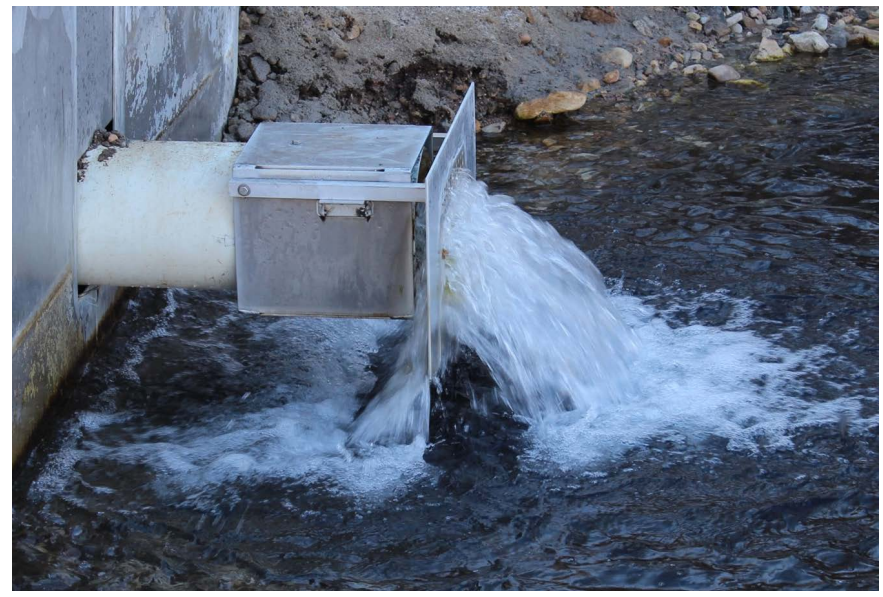

Figure 11. Picture of inlet structure in situ, operating position.

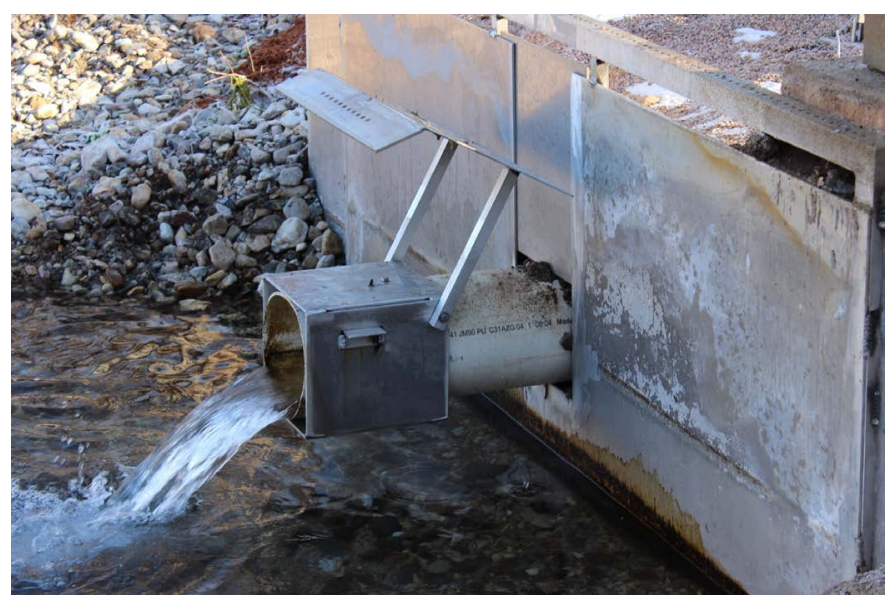

Figure 12. Picture of inlet structure in situ, cleaning position. 


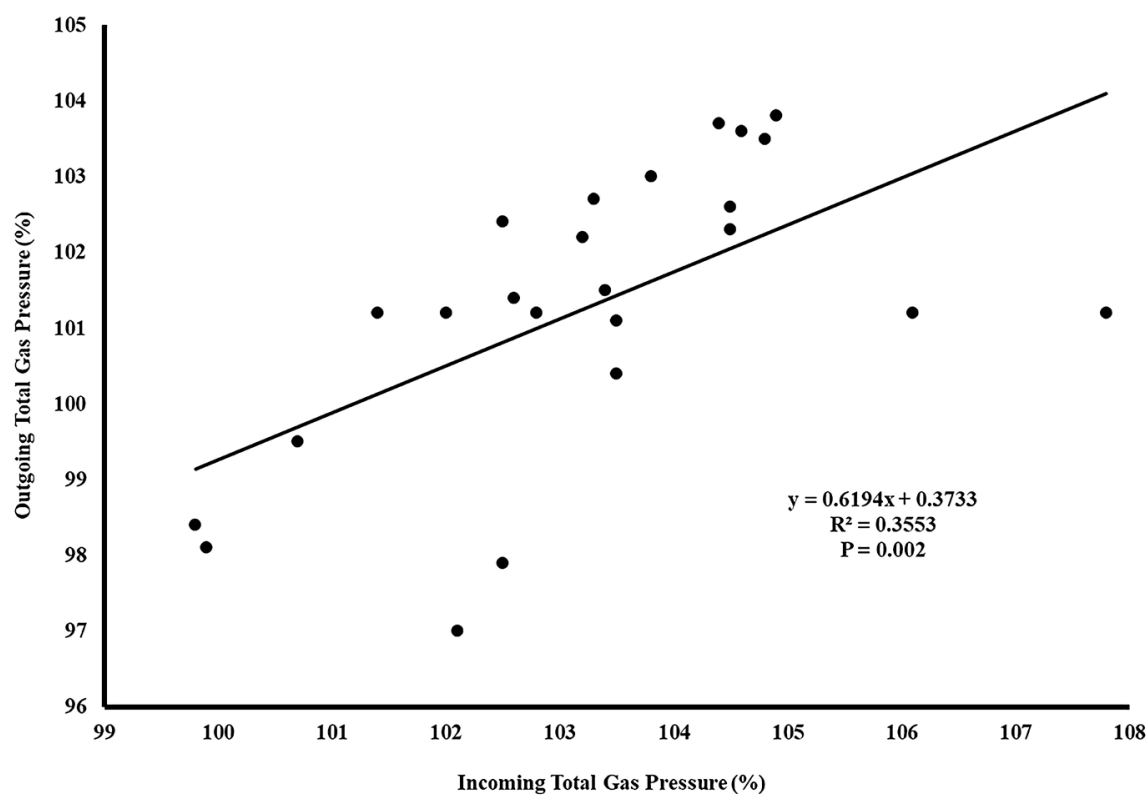

Figure 13. Relationship in total gas pressure (\%) in water entering and exiting the inlet structure.

decreased to as low as $97 \%$ with the use of the new structure. This evaluation occurred during the fall and winter months when total gas pressures may have been at their lowest concentrations. Gas supersaturation may vary seasonally and unpredictably in springs and may be the highest in the spring and summer [7] [13]. Although the absolute reduction in total gas pressures was not of a great magnitude, decreasing these values down to under $102 \%$ is highly beneficial to fish health. Other trout and salmon hatcheries have observed negative impacts on fish production with saturation levels as low as 104\% [7] [11]. Future research over a longer time frame to potentially capture peak total gas pressures that may be occurring during different times of the year is needed.

Other structures have been used to decrease gas supersaturation to levels more conducive to fish rearing. This splash plate, with its holes, slots, and angled surfaces, decreased gas supersaturation levels as well or better than cascades, splashboards, or weirs [14] [15] [16]. However, it was likely much easier to maintain than those type of structures.

\section{Conclusion}

This inlet structure is highly advantageous for use in production fish hatcheries. It combines ease of maintenance with affordability, while achieving the requirements to rear fish efficiently in ponds receiving supersaturated water from springs.

\section{Conflicts of Interest}

The authors declare no conflicts of interest regarding the publication of this paper. 


\section{References}

[1] Leitriz, E. and Lewis, R.C. (1976) Trout and Salmon Culture (Hatchery Methods). California Department of Fish and Game Fish Bulletin, Sacramento.

[2] Piper, R.G., McElwain, I.B., Orme, L.E., McCraren, J.P., Fowler, L.G. and Leonard, J.R. (1982) Fish Hatchery Management. United States Fish and Wildlife Service, Washington DC.

[3] Stickney, R.R. (1994) Principles of Aquaculture. Wiley and Sons, Inc., New York.

[4] Krebs, E., Muggli, A.M., Barnes, J.M. and Barnes, M.E. (2018) A Novel Trout Pond Inlet Structure. Journal of Aquaculture Engineering and Fisheries Research, 4, 120-126.

[5] Helfrich, L.A., Pardue, G.B. and Bromley, P.T. (1999) Solutions to Common Farm Pond Problems. Virginia Cooperative Extension, Virginia.

[6] Colt, J. (1986) Gas Supersaturation-Impact on the Design and Operation of Aquatic Systems. Aquacultural Engineering, 5, 49-85.

https://doi.org/10.1016/0144-8609(86)90005-1

[7] Marking, L.L. (1987) Gas Supersaturation in Fisheries: Causes, Concerns, and Cures. US Department of the Interior, Fish and Wildlife Service, Washington DC.

[8] Harvey, H.H. (1975) Gas Disease in Fishes-A Review. In: Adams, W.A., Greer, G., Desnoyers, J.E., Atkinson, G., Kell, G.S., Oldham, K.B. and Walkley, J., Eds., Chemistry and Physics of Aqueous Gas Solutions, The Electrochemical Society, Inc., Princeton, 450-485.

[9] Rucker, R.R. and Kangas, P.M. (1974) Effect of Nitrogen Supersaturated Water on Coho and Chinook Salmon. The Progressive Fish-Culturist, 36, 152-156. https://doi.org/10.1577/1548-8659(1974)36[152:EONSWO]2.0.CO;2

[10] Stroud, R.K., Bouck, G.R. and Nebeker, A.V. (1975) Pathology of Acute and Chronic Exposure of Salmonid Fishes to Supersaturated Water. In: Adams, W.A., Greer, G., Desnoyers, J.E., Atkinson, G., Kell, G.S., Oldham, K.B. and Walkley, J., Eds., Chemistry and Physics of Aqueous Gas Solutions, The Electrochemical Society, Inc., Princeton, 435-439.

[11] Weitkamp, D.E. and Katz, M. (1980) A Review of Dissolved Gas Supersaturation Literature. Transactions of the American Fisheries Society, 109, 659-702. https://doi.org/10.1577/1548-8659(1980)109<659:ARODGS>2.0.CO;2

[12] Lekang, O.-I. (2013) Aquaculture Engineering. Wiley and Sons, Ltd., West Sussex. https://doi.org/10.1002/9781118496077

[13] Bouck, G.R. (1984) Annual Variation of Gas Supersaturation in Four Spring-Fed Oregon Streams. The Progressive Fish-Culturist, 46, 139-140. https://doi.org/10.1577/1548-8640(1984)46<139:AVOGSI >2.0.CO;2

[14] Haskell, D.C., Davies, R.O. and Reckahn, J. (1960) Factors in Hatchery Pond Design. New York Fish and Game Journal, 7, 112-129.

[15] Chesness, J.L. and Stephens, J.L. (1971) A Model Study of Gravity Flow Aerators for Catfish Raceway Systems. Transactions of the ASAE, 14, 1167-1169. https://doi.org/10.13031/2013.38477

[16] Tebutt, T.H.Y. (1972) Some Studies on Reaeration in Cascades. Water Research, 6, 299-304. https://doi.org/10.1016/0043-1354(72)90007-3 